\title{
ART THERAPY SEBAGAI BENTUK DARI ACTIVITY THERAPY BAGI PENDERITA HIV YANG MENGALAMI KECEMASAN
}

\author{
Elisa Christina Jaman ${ }^{1}$, Denrich Suryadi², dan Linda Wati ${ }^{3}$ \\ ${ }^{1}$ Fakultas Psikologi, Universitas Tarumanagara Jakarta \\ Email: elisacj92@gmail.com \\ ${ }^{2}$ Fakultas Psikologi, Universitas Tarumanagara Jakarta \\ Email: angiedenrich@yahoo.com \\ ${ }^{3}$ Fakultas Psikologi, Universitas Tarumanagara Jakarta \\ Email: lindlindawati@gmail.com
}

\begin{abstract}
ABSTRAK
Penderita HIVIAIDS mengalami krisis kejiwaan pada dirinya, pada keluarganya, pada orang yang dicintainya dan pada masyarakat. Krisis kejiwaan tersebut adalah dalam bentuk kepanikan, ketakutan, kecemasan, serba ketidakpastian, keputusasaan, dan stigma. Penyakit dan akibat yang diderita, baik akibat penyakit ataupun intervensi medis tertentu dapat menimbulkan perasaan negatif seperti kecemasan, depresi, marah, ataupun rasa tidak berdaya dan perasaan-perasaan negatif tertentu yang dialami secara terus-menerus ternyata dapat memperbesar kecenderungan perasaan negatif seseorang terhadap suatu penyakit. Kecemasan adalah kekhawatiran yang tidak jelas, berkaitan dengan perasaan tidak pasti dan tidak berdaya. Penelitian ini bertujuan untuk mengetahui apakah penerapan art therapy dapat mengurangi tingkat kecemasan pada warga binaan yang positif mengidap HIV. Metode penelitian dilakukan dengan menggunakan desain kuasi-eksperimental. Pengambilan sampel dilakukan pada Lembaga Permasyarakatan X yang melibatkan lima orang warga binaan laki-laki yang positif mengidap HIV dan sedang dalam keadaan cemas. Untuk mengukur tingkat kecemasan alat ukur yang digunakan adalah General Anxiety Disorder 7 (GAD7). Metode intervensi yang digunakan adalah art therapy yang ditemukan dapat menurunkan kecemasan. Setelah sesi intervensi dilakukan, ditemukan adanya penurunan tingkat kecemasan pada kelima partisipan. Hal tersebut terlihat dari perbandingan skor antara skor pre-test dan post-test para partisipan.
\end{abstract}

Kata kunci: Art therapy, HIV, kecemasan, intervensi, lembaga pemasyarakatan, warga binaan.

\section{PENDAHULUAN}

\section{Latar Belakang}

Lembaga Permasyarakatan $\mathrm{X}$ adalah sebuah lembaga yang membina narapidana laki-laki yang memakai narkoba. Permasyarakatan dinyatakan sebagai suatu sistem pembinaan terhadap para pelanggar hukum dan sebagai suatu pengejawantahan keadilan yang bertujuan untuk mendapat reintegrasi sosial dan pulihnya kesatuan hubungan antara warga binaan Permasyarakatan dengan masyarakat. Permasyarakatan mulai dilaksanakan sejak tahun 1964 dalam UndangUndang no. 12 tahun 1995 tentang permasyarakatan.

Kondisi kesehatan di dalam Lapas dan Rutan menjadi masalah yang penting. Salive (1990) menyatakan bahwa narapidana di penjara memiliki resiko tinggi terinfeksi HIV ataupun TB. Sustowo (2008) menjelaskan bahwa ketika hunian penjara meningkat, menjadi dapat dipahami jika Lapas atau Rutan itu bukan menjadi tempat yang sulit untuk dapat melaksanakan pencegahan yang efektif dan menyediakan perawatan yang layak bagi penghuni dengan HIV/AIDS. Sampai saat ini terdapat 88 orang narapidana yang positif mengidap HIV di Lapas $\mathrm{X}$ dan diantaranya terdapat 10 orang yang telah meninggal dunia.

HIV/AIDS merupakan masalah global yang terjadi di seluruh dunia. Berdasarkan data terakhir yang dikeluarkan oleh UNAIDS pada tahun 2016, di Indonesia terdapat 620 ribu penduduk yang positif mengidap HIV (UNAIDS.org, 2016). HIV ditularkan khususnya dengan 
pertukaran cairan tubuh, yaitu cairan seksual dan darah (Taylor, 1995). Virus HIV hidup di semua cairan tubuh tetapi hanya bisa menular melalui cairan tubuh tertentu, yaitu: darah, air mani (cairan, bukan sperma), cairan vagina, dan air susu ibu (ASI). Ketika dokter mendiagnosis bahwa seseorang menderita penyakit kronis seperti AIDS, ada tiga bentuk respon emosional yang secara umum mungkin muncul yaitu penolakan, kecemasan, dan depresi (Taylor, 1995).

Hawari (2004) menjelaskan bahwa penderita AIDS akan mengalami krisis kejiwaan pada dirinya, pada keluarganya, pada orang yang dicintainya dan pada masyarakat. Krisis kejiwaan tersebut adalah dalam bentuk kepanikan, ketakutan, kecemasan, serba ketidakpastian, keputusasaan, dan stigma. Sarafino (1998) juga mengemukakan bahwa suatu penyakit dan akibat yang diderita, baik akibat penyakit ataupun intervensi medis tertentu dapat menimbulkan perasaan negatif seperti kecemasan, depresi, marah, ataupun rasa tidak berdaya dan perasaanperasaan negatif tertentu yang dialami terus-menerus ternyata dapat memperbesar kecenderungan seseorang terhadap suatu penyakit tertentu.

Meskipun reaksi psikologis terhadap diagnosis penyakit dan penanganan sangat beragam dan keadaan serta kemampuan masing-masing penderita tergantung pada banyak faktor, tetapi terdapat enam reaksi psikologis yang paling utama menurut Prokop (dalam Lubis, 2009) yaitu, kecemasan, depresi, perasaan kehilangan kontrol, gangguan kognitif (impairment), gangguan seksual serta penolakan terhadap kenyataan (denial).

Kecemasan adalah kekhawatiran yang tidak jelas, berkaitan dengan perasaan tidak pasti dan tidak berdaya (Stuart \& Laraia, 2005). Kecemasan dapat disebabkan oleh perasaan takut tidak diterima di lingkungan tertentu, pengalaman traumatis, rasa frustrasi akibat kegagalan mencapai tujuan, dan ancaman terhadap integritas diri serta konsep diri (CMHN, 2006). Berdasarkan hasil wawancara dengan para warga binaan yang positif mengidap HIV, mereka merasakan kecemasan yang sama mengenai keluarga. Warga binaan mencemaskan keadaan keluarga mereka di rumah, dan apakah keluarga mereka dapat menerima mereka lagi ketika mereka bebas nanti.

Penelitian yang dilakukan oleh Curry dan Kasser (2005) mendapatkan hasil bahwa art therapy dapat menurunkan kecemasan. Selain itu, art therapy tersebut dapat menjadi bentuk dari activity therapy untuk menghilangkan rasa kebosanan para warga binaan akibat tidak adanya kegiatan yang diikuti. Berdasarkan uraian di atas, penulis melakukan penelitian ini dengan tujuan untuk mengetahui apakah penerapan art therapy dapat menurunkan tingkat kecemasan terhadap keluarga yang dirasakan oleh para warga binaan yang positif mengidap HIV.

\section{Rumusan Masalah}

Rumusan masalah dalam penelitian ini adalah, "Apakah efektivitas art therapy sebagai bentuk dari activity therapy dapat mengurangi tingkat kecemasan pada warga binaan yang mengidap HIV?"

\section{METODE PENELITIAN \\ Partisipan}

Teknik pengambilan sampel dalam penelitian ini adalah purposive sampling. Penelitian ini melibatkan lima orang warga binaan laki-laki pada Lembaga Permasyarakatan X yang positif mengidap HIV serta mengalami kecemasan. 


\section{Desain Penelitian}

Penelitian ini dilakukan dengan menggunakan desain kuasi-eksperimental.

\section{Pengukuran}

Kuesioner yang digunakan dalam penelitian ini adalah General Anxiety Disorder 7 (Spitzer, 2001).

\section{Perlengkapan Penelitian}

Kuesioner yang digunakan dalam penelitian ini adalah General Anxiety Disorder 7 (Spitzer, 2001) yang diberikan pada awal dan akhir intervensi untuk mengetahui apakah kecemasan partisipan berkurang setelah diberikan intervensi. Selain itu, perlengkapan yang diperlukan selama penelitian dilakukan adalah lembar biodata, lembar informed consent, serta alat lukis (kertas gambar A3, pensil, penghapus, cat poster, kuas, air, tisu, dan container air).

\section{Persiapan dan Prosedur Penelitian}

Langkah pertama yang dilakukan penulis adalah memberitahu kriteria partisipan yang dibutuhkan kepada pengurus Lembaga Pemasyarakatan X. Setelah mendapatkan partisipan yang sesuai dengan kriteria, proses intervensi art therapy dilakukan sebanyak tujuh sesi. Penelitian ini menggunakan kuesioner General Anxiety Disorder 7 (GAD7) untuk mendapatkan skor pre-test dan post-test.

\section{Lokasi Penelitian}

Penelitian dilakukan pada salah satu ruangan di Lembaga Permasyarakatan X.

\section{HASIL DAN PEMBAHASAN \\ Gambaran Partisipan}

Secara keseluruhan, kelima partisipan mempunyai skor kecemasan sebesar 10-12 dari kuesioner GAD7 sebelum intervensi diberikan.

Tabel 1. Skor Pre-test GAD7 Partisipan

\begin{tabular}{cc}
\hline Klien & Pre-test GAD7 \\
\hline HA & 12 \\
W & 12 \\
BM & 10 \\
DS & 10 \\
SF & 11 \\
\hline
\end{tabular}

\section{Pelaksanaan Intervensi}

Proses evaluasi dilakukan di awal dan di akhir intervensi untuk mengetahui apakah kecemasan partisipan berkurang setelah diberikan intervensi. Durasi yang diperlukan untuk intervensi disesuaikan dengan kecepatan partisipan dalam mengikuti intervensi pada setiap sesi. Berikut adalah prosedur intervensi yang dilakukan pada partisipan. 


\section{Tabel 2. Prosedur Intervensi}

\begin{tabular}{|c|c|c|}
\hline Sesi & Kegiatan & Tujuan \\
\hline \multirow[t]{6}{*}{1} & Perkenalan, penjelasan tujuan terapi & Membangun rapport antar peserta, peserta \\
\hline & kelompok, aturan selama terapi & saling mengenal peserta kelompok lainnya. \\
\hline & kelompok. & Mencoba untuk menggambar bebas. \\
\hline & Menggambar bebas. & Mendiskusikan mengenai apa yang \\
\hline & Diskusi kelompok. & digambar, pikiran dan perasaan ketika \\
\hline & & menggambar. \\
\hline \multirow[t]{6}{*}{2} & "Who would I be without my anxiety?" & Peserta melepaskan kecemasan, belajar \\
\hline & & untuk menghargai diri sendiri (Buchalter, \\
\hline & Diskusi kelompok. & 2009). \\
\hline & & Mendiskusikan mengenai apa yang \\
\hline & & digambar, pikiran dan perasaan ketika \\
\hline & & menggambar. \\
\hline \multirow[t]{8}{*}{3} & Laughter. & Peserta sadar akan hubungan positif dari \\
\hline & & senyuman (Buchalter, 2009). \\
\hline & Diskusi kelompok. & Mendiskusikan mengenai apa yang \\
\hline & & digambar, pikiran dan perasaan ketika \\
\hline & & menggambar. \\
\hline & & Diskusi fokus pada bagaimana humor dan \\
\hline & & tertawa dapat bermanfaat secara fisik dan \\
\hline & & emosional. \\
\hline \multirow[t]{7}{*}{4} & Mandala. & Menurunkan kecemasan (Slayton, \\
\hline & & D’Archer, \& Kaplan, 2010) dan mengetahui \\
\hline & & ego state peserta setelah mengikuti sesi \\
\hline & & tentang kecemasan. \\
\hline & & Mendiskusikan mengenai apa yang \\
\hline & Diskusi kelompok. & digambar, pikiran dan perasaan ketika \\
\hline & & menggambar. \\
\hline \multirow[t]{7}{*}{5} & Custom. & Mengetahui ritual di dalam keluarga, \\
\hline & & meningkatkan harga diri dan perasaan \\
\hline & & terhubung dengan keluarga (Buchalter, \\
\hline & & 2009). \\
\hline & Diskusi kelompok. & Mendiskusikan mengenai apa yang \\
\hline & & digambar, pikiran dan perasaan ketika \\
\hline & & menggambar. \\
\hline
\end{tabular}




\begin{tabular}{cc}
\hline Support. & $\begin{array}{c}\text { Serta berbagi pengalaman yang } \\
\text { menyenangkan di dalam keluarga. }\end{array}$ \\
\hline 6 & Mengetahui orang lain yang mendukung \\
peserta selama masa hidupnya terutama di \\
dalam keluarga (Buchalter, 2009). \\
Diskusi kelompok. & Mendiskusikan mengenai apa yang \\
& digambar, pikiran dan perasaan ketika \\
& menggambar. \\
& Selain itu peserta diminta untuk berbagi \\
& pengalaman hidupnya saat mereka menjadi \\
& pendukung dan saat mereka membutuhkan \\
& dukungan. \\
\hline 7 & Mengajak peserta untuk review atas semua \\
& sesi terapi yang sudah dilakukan. \\
& Mengetahui efektivitas terapi pada para \\
& peserta. \\
& Galuasi dan terminasi.
\end{tabular}

\section{Hasil Intervensi}

Setelah intervensi dilakukan, kecemasan DS mengalami penurunan yang lebih signifikan dibandingkan dengan partisipan lainnya. Selama mengikuti sesi, DS lebih serius dalam mendengarkan instruksi dan mengerjakan tugas. DS serius ketika menceritakan apa yang ia kerjakan selama proses intervensi berlangsung kepada partisipan lainnya. Ia juga menjelaskan apa yang ia rasakan serta apa yang ia pikirkan selama mengerjakan tugas.

Berbeda dengan DS, partisipan lainnya yaitu HA tidak selalu datang tepat waktu, W tidak selalu menuruti instruksi tugas yang diberikan, BM mengerjakan tugas secara terburu-buru, dan SF tidak dapat mengikuti instruksi dengan baik. Selain itu, selama mengikuti sesi intervensi, $\mathrm{W}$ tidak datang mengikuti sesi intervensi sebanyak satu kali.

Tabel 3. Skor Post-test GAD7 Partisipan

\begin{tabular}{ccc}
\hline Klien & Pre-test GAD7 & Post-test GAD7 \\
\hline HA & 12 & 9 \\
W & 12 & 11 \\
BM & 10 & 8 \\
DS & 10 & 5 \\
SF & 11 & 9 \\
\hline
\end{tabular}

\section{KESIMPULAN DAN SARAN}

Berdasarkan hasil evaluasi, ditemukan adanya penurunan tingkat kecemasan pada kelima partisipan. Hal tersebut dapat dilihat dari perbandingan skor antara skor pre-test dan post-test para partisipan. 


\section{Diskusi}

Berdasarkan penelitian yang dilakukan oleh Curry dan Kasser (2005) serta penelitian yang dilakukan, art therapy dapat menurunkan kecemasan. Selain itu, art therapy dapat menjadi bentuk dari activity therapy untuk menghilangkan rasa kebosanan para warga binaan akibat tidak adanya kegiatan yang diikuti. Walaupun hasil penelitian tidak dapat diuji secara statistik karena jumlah partisipan yang terlalu sedikit, namun hasil penelitian menemukan bahwa art therapy dapat menurunkan kecemasan secara spesifik.

Menurut hasil pre-test dan post-test, hanya $\mathrm{W}$ yang memiliki penurunan tingkat kecemasan yang paling rendah yaitu satu poin. Hal ini dapat dijelaskan karena $\mathrm{W}$ kurang kooperatif selama mengikuti sesi intervensi. Berdasarkan observasi, W datang terlambat sebanyak dua kali dan W tidak datang mengikuti sesi intervensi sebanyak satu kali. Walaupun W mengikuti sesi intervensi pengganti, kedua hal tersebut dapat memengaruhi skor penurunan tingkat kecemasan W. Selain itu, dari kelima partisipan hanya DS yang memiliki penurunan tingkat kecemasan yang paling tinggi yaitu lima poin. Hal ini dapat dijelaskan karena DS memiliki sifat kooperatif selama mengikuti sesi intervensi. DS juga mempunyai inisiatif untuk berpartisipasi selama sesi sharing.

\section{Saran Kepada Peneliti Selanjutnya}

Apabila penelitian serupa akan dilakukan, perlu untuk dipertimbangkan sudah berapa lama partisipan mengetahui bahwa ia telah positif mengidap HIV sampai pada saat penelitian dilakukan.

\section{Ucapan Terima Kasih}

Penulis berterima kasih kepada para partisipan yang terlibat selama proses penelitian ini berlangsung. Penulis mengucapkan terima kasih kepada Lembaga Pemasyarakatan X yang telah memberikan kepercayaan kepada penulis untuk melakukan penelitian ini. Penulis juga mengucapkan terima kasih kepada Ibu Denrich dan Ibu Linda yang memberikan bantuan berupa masukan serta arahan dalam penyusunan penelitian ini.

\section{REFERENSI}

Buchalter, S. I. (2009). Art therapy techniques and application. Britain: Athenaeum Press, Gateshead, Tyne and Wear.

CMHN. (2006). Modul basic course community mental health nursing. Jakarta: WHO FIK UI. Hawari, D. (2004). Al Qur'an: Ilmu Kedokteran Jiwa dan Kesehatan Jiwa”. Edisi III (Revisi). Yogyakarta: PT. Dana Bhakti Prima Yasa.

Kroenke, K., Spitzer, R. L., \& Williams, J. B. W. (2001). The PHQ-9: Validity of a brief depression severity measure. Journal of General Internal Medicine, 16(9), 606-613. http://doi.org/10.1046/j.1525-1497.2001.016009606

Lubis, N.L. (2009). Depresi: Tinjauan Psikologis. Jakarta: Kencana.

Sarafino, E.P. (1998). Health Psychology: Biopsychosocial Interaction. New York: John Wiley $\&$ Sons Inc.

Slayton, S. C., D’Archer, J., \& Kaplan, F. (2010). Outcome Studies on the Efficacy of Art Therapy: A review of Findings. Art therapy: Journal of the American art therapy association, 27(3), 108-118.

Stuart, G. W., \& Laraia, M. T. (2005). Principles and practice of psychiatric nursing. ( $8^{\text {th }}$ ed.). St. Louis: Mosby Year B.

Taylor, S.E. (1995). Health Psychology. Third Edition. New York: inc. Mc. Graw Hill. 
Art Therapy Sebagai Bentuk dari Activity Therapy

Elisa Christina Jaman, et al.

Bagi Pendetita HIV yang Mengalami Kecemasan

UNAIDS. (2016). Number of people living with HIV. http://aidsinfo.unaids.org. 7 September 2017.

Yosep, I. (2007). Keperawatan Jiwa. Bandung: Refika Aditama. 